\title{
Improving the Quality of Education in Public Primary School
}

\author{
Masuri \\ SD Negeri 22 Banyuasin III \\ e-mail: masuri886@gmail.com \\ Happy Fitria \\ Universitas PGRI Palembang \\ e-mail: happyfitriamufly@univpgri-palembang.ac.id \\ Mulyadi \\ Universitas PGRI Palembang \\ e-mail: mulyadi@univpgri-palembang.ac.id \\ Article History: Received on 5 November 2021, Revised on 15 January 2022 \\ Published on 21 January 2022
}

\begin{abstract}
This study described the quality of learning in Public Primary Schools 22 Banyuasin III. The qualitative method was used in the study. Informants were headmaster and teachers. Data were collected using interviews. The results showed that the management of grade teachers in the implementation of the teaching process relevant with the era of the industrial revolution 4.0. The obstacles were lack of visual aids.
\end{abstract}

Keywords: Quality, Education, Primary School

\section{A. Introduction}

Through the management, the school principals will be able to transfer some value as an emphasis to support teachers and employees (Kristiawan, 2017). In an effort to maintain and improve performance employees needed a leader who use their role in carrying out tasks and able person can also read the inferiors and the workplace. According to Mulyasa (2013) there are several factors that made a leader can improve the quality of education. First, leader meets the needs of inferiors related to the effectiveness of work. Second, leaders give a workout, guidance and support required employees. The lack of quality learning can caused by several factors as was said by Mulyasa (2013) the subject matter the decline in morals, students equity, learning opportunities the limited efficiency internal, education system, institutional status management education are not in accordance with national development and resources. School principals at least should be able to serve as educator, manager, administrator, supervisor, leader, innovator, motivator, and entrepreneur (Danim, 2012).

The quality of institution is the most serious problem. The quality of education in the future needs the entire thinker and education experts, whose various ways, a method, approach, strategies and policies (Hasibuan et al, 2019). There are 22 Public Primary Schools in Banyasin III which still low the quality of learning. This condition can be assessed in terms of infrastructure, curriculum, program, the media and utensil. If it does not fulfill the infrastructure, curriculum, program, and media it will affect the difficulty to obtain a new students. When we did observations, obtained information that learning done in the morning 

pm.

This research is supported by Lian (2019) managerial competence of school principals in improving the performance of teachers at junior integrated Islamic Al-Fityan. Sudrajat (2018) reminded through relevant assessment provides inspiration for us to do this study. This research can contribute to school principals to improve the quality of their experiences.

\section{B. Methods}

This study is qualitative. This study specifically designed to describe the social phenomena in the pertaining the management learning in Public Primary Schools in the industrial revolution. The Informants interviewed in this research were public elementary school teachers. The data were collected using interviews, observation and documentation. Then the data were analyzed by the following triangulation. To test the credibility of the data it was done by checking the data that has been obtained through informants. This is done to obtained the truth value (Sugiyono, 2015; Prastowo, 2011; Moleong, 2011).

\section{Results and Discussion}

Professional principal is not that easy as imagined, it is associated with the dynamics of current trends, and demands accountability. The principal challenges larger in carrying out tasks and functions. This occurred because of an authority and hierarchy of the superior authority over supreme. Another challenge facing school principals in the future are ensuring the sustainable quality learning, integrating the basic knowledge and skill, manage behavior and the presence of personnel at the school, managing resources and its environment in a strategic, build schools as professional learning community center, and developing partnerships and cooperation not only in the context of school but seek support from parents and the community to synchronize and develop opportunity. Challenges the dynamics, the school principal could not move alone. As a component part of the government authority, the support and commitment of local governments including education office at the provincial level, countries and cities are vital prerequisite. Support and commitment of the regional government has to be considered as long term investments who is developing more developed the education sector. The investment in time, energy, money, and other relevant resources (Gangsar, 2012; Harapan \& Kesumawati, 2020).

Through management, school principals be able to transfer some value, as in support teachers and employees, sanction to risk (Pieterlase, 2019). School as an organization in improving the quality of school should see all of components. All components responsible for their respective tasks and functions. The total quality is total in three sense: it cover every party, every job, and every person. Quality national educational directed to the potency advancement students to be people who believe and fear one god, noble, healthy, knowledge, creative, independently, democratic and responsible. The quality possessed by a product or service should meet the need or expectation, and satisfaction. Internal customer is student and external customer is the community and industry. Quality those are not stand alone (Fitria, 2019; Kurniasih, 2017).

The quality of learning determined by three variables, the culture or habit of school, teaching and learning, and reality of the school. Habit in schools that either teachers or students affecting the quality learning in school. When teachers teach in the classroom, it can affect the quality 
Volume 2 (3) 2021

E-ISSN: 2723-6919 P-ISSN: 2746-0827

learning. Fitria (2019) found that management infrastructure improved learning. The result of this research explained that 14 items do not meet the standards, the infrastructure which not meet standards: classrooms, the library, the biological laboratories, the physics laboratory, the computer laboratories, space laboratory language, teachers office, the nurse, a student organization, privy, warehouse, the circulation, and the sporting goods. Harapan and Kesumawati (2020) told the the quality of teachers as an effort to increase the authority school. The results concluded that the quality of teachers in Public Primary Schools increase the school authority. It has similarities and differences by research now, the equally research pertaining to the quality of learning. Research management examined leadership of school principals in improving the quality of learning. Mulyasa (2019) management leadership of school principals in teacher professional development. The result of this research concluded that 1) management leadership of school principals in professional training for primary public school teachers betung 12 is good in terms of planning can be seen, organizing, the implementation, evaluation and follow up 2) the obstacles is the lack of information, only certain rely on teachers, the limited financial and lack of knowledge for developing professional teachers 3) solution of obstacles is conducting training, supervision, giving the assignment and conduct capacity building (Nuryani et al, 2021; Maryati et al, 2021; Lydia et al, 2021).

\section{Conclusion}

Based on the results, it concludes that the implementation of the teacher management class learning on public primary schools in the industrial revolution 4.0 is considered good and capable of management the implementation of the learning. Obstacles that teachers face in the implementation of the learning were lack of information, only certain rely on teachers, the limited financial and lack of knowledge for developing professional teachers.

\section{E. Acknowledgement}

We thank to SD Negeri 22 Banyuasin III, Rector Universitas PGRI Palembang, Director of Graduate Program and friends of graduate program educational management Universitas PGRI Palembang who have supported us to do this project.

\section{References}

Danim, S., (2012). Administrasi Sekolah dan Manajemen Kelas [School Administration and Classroom Management]. Bandung: Pustaka Setia.

Fitria, H. (2019). Manajemen Sarana Prasarana dalam Meningkatkan Proses Pembelajaran [Infrastructure Management in Improving the Learning Process]. Prosiding Seminar Nasional Pendidikan Program Pascasarjana Universitas PGRI Palembang 12 January 2019, 58-65.

Gangsar, F. U. (2012). Kemampuan Guru Mengelola Kelas 4 dan 5 SD Negeri Pandeyan Umbulharjo Yogyakarta [Teacher Ability to Manage Grades 4 and 5 SD Negeri Pandeyan Umbulharjo Yogyakarta]. Jurnal Manajemen Pendidikan, 3(2), 236-251.

Harapan, E., \& Kesumawati, N. (2020) Kualitas Guru Mengajar Sebagai Salah Satu Upaya Meningkatkan Status Akreditasi Sekolah [Quality of Teaching Teachers as an Effort to 
Improve School Accreditation Status]. JMKSP (Jurnal Manajemen, Kepemimpinan, dan Supervisi Pendidikan), 6(1), 124-132.

Hasibuan., Ahmad., \& Tarmizi. (2019). Sekolah Ramah Anak Era Revolusi Industri 4.0 di SD Muhammadiyah Pajangan 2 Berbah Yogyakarta [Child Friendly Schools in the Industrial Revolution Era 4.0 at Muhammadiyah Elementary School Pajangan 2 Berbah Yogyakarta]. Jurnal Manajemen Pendidikan, 11(01).

Kristiawan, M., Safitri, D., \& Lestari, R. (2017). Manajemen Pendidikan [Education Management]. Yogyakarta: Deepublish.

Kurniasih, I. (2017). Kompetensi Pedagogik, Teori dan Praktik Untuk Peningkatan Kinerja dan Kualitas Guru [Pedagogic Competence, Theory and Practice for Improving Teacher Performance and Quality]. Jakarta: Kata Pena.

Lian, B. (2019). Revolusi Industri 4.0 dan Disrupsi, Tantangan dan Ancaman Bagi Perguruan Tinggi [Industrial Revolution 4.0 and Disruption, Challenges and Threats for Higher Education]. Prosiding Seminar Nasional Pendidikan Program Pascasarjana Universitas PGRI Palembang 12 January 2019, 40-45.

Lydia, L., Fitria, H., \& Puspita, Y. (2021). Policy Implementation of Educational Quality Improvement Based on National Education Standard. Journal of Social Work and Science Education, 1(3), 221-233. https://doi.org/10.52690/jswse.v1i3.109

Maryati, S., Ahmad, S., \& Eddy, S. (2021). Management for Improving the Quality of Student Learning in Primary Schools. Journal of Social Work and Science Education, 1(3), 257265. https://doi.org/10.52690/jswse.v1i3.113

Moleong, L. (2011). Metodologi Penelitian Kualitatif [Qualitative Research Methodology]. Bandung: Remaja Rosdakarya.

Mulyasa, E. (2013). Standar Kompetensi dan Sertifikasi Guru [Teacher Competency and Certification Standards]. Bandung: Rosdakarya.

Mulyasa, E. (2019). Membangun Karakter Bangsa Melalui Pendidikan di Abad 21 [Building National Character Through Education in the 21st Century]. Bandung: Rosdakarya.

Nuryani, N., Harapan, E., \& Wardiah, D. (2021). Principal's Managerial in Improving the Quality of Education in Primary School. Journal of Social Work and Science Education, 2(1), 52-59. https://doi.org/10.52690/jswse.v2i1.205

Pieterlase. (2019). Pendidikan di Era Revolusi Industri 4.0 [Education in the Industrial Revolution 4.0]. Jurnal Sunderman, XIV(3), 28-43.

Prastowo, A. (2011). Penelitian Kualitatif: Teknik Mendesain Pembelajaran [Qualitative Research: Learning Design Techniques]. Yogyakarta: Diva Press.

Sudrajat. (2018). Manajemen Kinerja Guru Sekolah Dasar [Elementary School Teacher Performance Management]. Jurnal Administrasi Pendidikan, XXV(1), 104-119. 
Journal of Social Work and Science Education

Volume 2 (3) 2021

E-ISSN: 2723-6919 P-ISSN: 2746-0827

Sugiyono. (2015). Metode Penelitian Pendidikan, Pendekatan Kuantitatif, Kualitatif dan $R$ \& D [Educational Research Methods, Quantitative, Qualitative and R\&D Approaches]. Bandung: Alfabeta. 